\title{
Dewey's Concepts of Stability and Precariousness in His Philosophy of Education
}

\section{Fred Harris}

\begin{abstract}
This article connects two of Dewey's generic traits of existence-stability and precariousness - to four elements specified in his preface to Democracy and Education (democracy, evolution, industrialization and the experimental method) and one element specified in his preface to How We Think (childhood). It argues that Dewey's metaphysics of stability and precariousness is implicit in his philosophy of education and provides a unifying aspect to his philosophy of education that is relevant to the modern world. The article then briefly looks at whether Dewey developed a metaphysics at all and concludes that Dewey did indeed develop a metaphysics-a new metaphysics of human experience-which needs to be further analysed in relation to various aspects of his philosophy of education.
\end{abstract}

Richard Rorty, negatively, claims that John Dewey's metaphysics, especially as expounded in his work Experience and Nature follows a mistaken path by referring to generic traits of existence. ${ }^{1}$ The best thing in that work, according to Rorty, is its negative function. It exposes the pseudo-nature of philosophical problems and the consequent need to slough off the dualistic presuppositions of such pseudoproblems. On the other hand, Dewey, when he offered what he considered being something positive in that work metaphysically through the generic traits of existence, confused the causal process of believing something and the justification of that belief. Dewey's metaphysics of the generic traits of existence, on such a reading, has no real function to perform.

A similar disparagement of Dewey's metaphysics is found in Richard Gale's article, which derides Dewey's metaphysics by arguing that Dewey had a HumptyDumpty theory of metaphysics, designed to prevent the separation of the world into discrete particles that would, if left in isolation, never be unified again. ${ }^{2} \mathrm{On}$ such a reading, Dewey's metaphysics merely functioned to underscore his latent Hegelianism.

Instead of arguing against such views by extensively considering Dewey's metaphysics (as does, for example, Raymond Boisvert), ${ }^{3}$ the essay will argue indi- 
rectly for it at a more concrete level in relation to Dewey's philosophy of education. In particular, it will be seen that Dewey's concepts of stability and precariousness play a decisive role in his formulation of a philosophy of education in the modern, industrial epoch. It will, as a consequence, be clearer what Rorty's rejection of Dewey's metaphysics means.

Once the connection between Dewey's concepts of stability and precariousness and his philosophy of education has been established, the question of whether Dewey had a metaphysics at all will be briefly addressed.

For Dewey, existence is neither purely open nor purely closed. If it were purely closed, there would be no problems, no tension and no need to do or undergo or learn anything; experience would not arise. If it were purely open, there would be a constant flux of problems, with no stable points, no beginnings, no middles and no ends; learning would be useless. As Boisvert remarks, "As far as Dewey is concerned, change alone allows for no solutions, while permanence alone provides no problems."

The nature of existence itself as a unity or synthesis of being and becoming provides the basis for human learning:

We are here concerned with the fact that it is the intricate mixture of the stable and the precarious, the fixed and the unpredictably novel, the assured and the uncertain, in existence which sets mankind upon that love of wisdom which forms philosophy. ${ }^{5}$

This mixture is dialectical in that one cannot exist without the other; they presuppose each other or are internal to each other and yet not identical or reducible to each other. There is thus an ontological gap between a purely closed world and a purely open world. The two can never collapse into each other without annihilating existence.

Given that all existence is characterized by both stability and precariousness, the problem now is to connect those aspects of Dewey's ontology to his philosophy of education. The solution to the problem of how to link Dewey's metaphysics to his philosophy of education is suggested, in part, by Dewey himself in his reference to the importance of his philosophy of education to his general philosophy:

Although a book called Democracy and Education was for many years that in which my philosophy, such as it is, was most fully expounded, I do not know that philosophic critics, as distinct from teachers, have ever had recourse to it. I have wondered whether such facts signified that philosophers in general, although they are themselves usually teachers, have not taken education with sufficient seriousness for it to occur to them that any rational person could actually think it possible that philosophizing should focus about education as the supreme human interest in which, moreover, other problems, cosmological, moral, logical, come to a head. ${ }^{6}$

Indirectly, Ralph Sleeper's contention that Dewey's prefaces were designed so that the reader "would see the relevance of his thought to the world in which he was 
writing"7 also provides a clue for the solution. Dewey's own prefaces in his educational works may provide a clue to how his metaphysics is incorporated into his philosophy of education.

Dewey's preface to Democracy and Education contains the following:

As will appear from the book itself, the philosophy stated in this book connects the growth of democracy with the development of the experimental method in the sciences, evolutionary ideas in the biological sciences, and the industrial reorganization, and is concerned to point out the changes in subject matter and method of education indicated by these developments. ${ }^{8}$

There are four explicitly interrelated elements mentioned that thus relate to Dewey's philosophy of education: democracy, the experimental method, evolution and industrialization. A passage from the preface to How We Think links children's attitudes to one element of the former preface, namely, the experimental method:

This book represents the conviction that the needed steadying and centralizing factor is found in adopting as the end of endeavor that attitude of mind, that habit of thought, which we call scientific. This scientific attitude of mind might, conceivably, be quite irrelevant to teaching children and youth. But this book also represents the conviction that such is not the case; that the native and unspoiled attitude of childhood, marked by ardent curiosity, fertile imagination, and love of experimental inquiry, is near, very near, to the attitude of the scientific mind. ${ }^{9}$

Since Dewey's preface to Democracy and Education implies that the four elements are interrelated, and the preface in How We Think implies that children are related "to the attitude of the scientific mind," it can be inferred that childhood is linked to the four interrelated elements specified in the former preface.

The task is to link the five elements in a coherent fashion to Dewey's philosophy of education via the two metaphysical or generic traits of existence (stability and precariousness).

At the level of human society, human beings must have had to learn to deal with the stable and the precarious. Ideally, there should be a correspondence or conjugate relation between the stable and the precarious. It is the democratic ideal which illustrates the principle of the interpenetration of the precarious and the stable via an evolutionary process. The democratic form permits the transformation of individual variations (precariousness) into public forms (stability) which are serviceable to all individuals since they assume a general form-evolution. ${ }^{10}$ The democratic form is the social equivalent of the selection process of evolution.

The democratic form goes hand in hand with an industrial society; revolutions in technology under industrial capitalism occur relatively rapidly. Indeed, Dewey implies that industrialization created the need for a democratic community:

The widening of the area of shared concerns, and the liberation of a greater diversity of personal capacities which characterize a democracy, are not of 
course the product of deliberation and conscious effort. On the contrary, they were caused by the development of modes of manufacture and commerce, travel, migration, and intercommunication which flowed from the command of science over natural energy. ${ }^{11}$

Variations in the material environment of individuals goes hand in hand with variations in their social environment as the relations between people become more extensive physically (spatially) and complex (qualitatively). More extensive and complex relations in turn result in greater variation among individuals, since there is increased interaction. Environing conditions of individual members of the human species frequently change as a consequence in a continuous circle.

If stability is to occur, individual variations, rather than being suppressed, must be fostered. In such a situation, individual variations are at a premium, since it is these variations, and not the old, fixed ways, which will more likely provide the basis or means for the integration of the new environment with the individuals.

Such a society needs to "capture" individual variations, since it can advance only through such variations. These variations are unique:

... he [Plato] had no perception of the uniqueness of individuals.... There being no recognition that each individual constitutes his own class, there could be no recognition of the infinite diversity of active tendencies and combinations of tendencies of which an individual is capable. ${ }^{12}$

Plato also did not recognize that stability could arise through change:

But it is true that lacking the perception of the uniqueness of every individual, his incommensurability with others, and consequently not recognizing that a society might change and yet be stable, his doctrine of limited powers and classes came in net effect to the idea of the subordination of individuality. ${ }^{13}$

Democracy and industrialization correspond to each other, since they are merely two sides of the same coin: variations in individuals that are actively preserved in the face of variations in the environment. The preservation of variations in individuals is achieved through conscious sharing of the goals as ends-in-view. Since these goals are not immediately uniform but are a result of a process of the incorporation of individual variation through negotiation as to what is to be achieved-democracy-they will necessitate not only shared interest but varied interest according to the nature of the individuals involved in the process. This process will also necessarily involve free interaction so that no one group can dominate over others; the social environment will become richer in content as a consequence and so too will the individuals' experiences: "How numerous and varied are the interests which are consciously shared? How full and free is the interplay with other forms of association?"14

The correspondence between democracy and industrialization, however, is a need or a demand and not an empirical reality. Given industrialization, a democratic way of life is required. Dewey was a stern critic of industrialization in its capitalist 
form because it was undemocratic and, in fact, a dictatorship that prevented individual variation from bearing the maximum possible fruit for itself and for society. The need for the interpenetration of democracy and industrialization thus implied a demand for industrial or workplace democracy. ${ }^{15}$

Democracy, evolution and industrialization are thus intimately linked to the generic traits of stability and precariousness. Industrialization is also linked to the incorporation of the experimental method, since the latter grew out of the practical industrial occupations, such as mechanics. ${ }^{16}$ Moreover, the experimental method provides another way for the unification of the variable and the stable, since it searches out consciously new kinds of things by varying the conditions within which objects interact and hence opens up the possibility of finding novel kinds (new stable means) by means of such variation. ${ }^{17}$ The modern scientific method, unlike Aristotelian scientific method, does not consider an object as fixed in kind but as potentially always more than what it is because of the potentiality of further different ways of interacting with other things.

It has thus been shown that four of the five elements specified above are linked to the two generic traits of precariousness and stability. Although two of those elements-democracy and industrialization-may correspond to each other, there is no guarantee that they will do so: "But after greater individualization on one hand, and a broader community of interest on the other have come into existence, it is a matter of deliberate effort to sustain and extend them."18 It is only through the persistently conscious coordination of variations in the environment and the variations in the nature of individuals that stability can be achieved:

A society which is mobile, which is full of channels for the distribution of a change occurring anywhere, must see to it that its members are educated to personal initiative and adaptability. Otherwise, they will be overwhelmed by the changes in which they are caught and whose significance or connections they do not perceive. The result will be a confusion in which a few will appropriate to themselves the results of the blind and externally directed activities of others. ${ }^{19}$

It is the function of education to identify the unique capacities of individuals, develop them and link them to the social needs of an industrial, scientific society because such a society thrives only through experimental change. Only through nurturing individual variations and rendering those variations open to a public forum can the possibilities of individual variations be harnessed to the stabilization of the changing environmental conditions. That nurturing is education:

... a society is stably organized when each individual is doing that for which he has aptitude by nature in such a way as to be useful to others (or to contribute to the whole to which he belongs); and that it is the business of education to discover these aptitudes and progressively to train them for social use. ${ }^{20}$

How childhood fits into the schema now needs to be developed. 
For human beings, there is a material necessity for social nurturing because of the relatively large gap between the undeveloped capacities of human infants and their needs; these needs at first can only be met by other, older human beings. That gap, of course, varies with the species, but the gap among human infants is far more extensive than with any other species. This enduring gap means that physical dependence on the environment, characteristic of all animate beings, is translated into social dependence as a mediating factor that is materially necessary for the continued being of the human infant. The material being of individual human life is inextricably linked to its social being:

The thoroughgoing character of this helplessness suggests, however, some compensating power. The relative ability of the young of brute animals to adapt themselves fairly well to physical conditions from an early period suggests the fact that their life is not intimately bound up with the life of those about them. They are compelled, so to speak, to have physical gifts because they are lacking in social gifts. Human infants, on the other hand, can get along with physical incapacity just because of their social capacity ... observation shows that children are gifted with an equipment of the first order for social intercourse. Few grown-up persons retain all of the flexible and sensitive ability of children to vibrate sympathetically with the attitudes and doings of those about them. Inattention to physical things (going with incapacity to control them) is accompanied by a corresponding intensification of interest and attention as to the doings of people. ${ }^{21}$

The physical dependence of human infants on the adult members of the species is much greater than the infants of other species, but their capacity for varying their behaviours is much greater than non-human animals. In terms of the concepts of precariousness and stability, non-human animals tend physiologically toward stability (fixed capacities) whereas human beings tend toward precarious capacities which constitute a basis for their transformation into stable capacities via learning.

Although human beings as a species tend toward variability, they simultaneously need stable relations that transform their variable capacities into a more stable (but still flexible) form. It is the function of older humans to provide that stability for the younger ones. Older human beings would not be human if there were no younger and immature humans who elicited their cooperative actions and stabilizing function:

The importance for human life of the two facts of dependence and variable control has been summed up in the doctrine of the significance of prolonged infancy. This prolongation is significant from the standpoint of the adult members of the group as well as from that of the young. The presence of dependent and learning beings is a stimulus to nurture and affection. The need for constant continued care was probably a chief means in transforming temporary cohabitations into permanent unions. It certainly was a chief influence in forming habits of affectionate and sympathetic watchfulness; that constructive interest in the well-being of others which 
is essential to associated life. Intellectually, this moral development meant the introduction of many new objects of attention; it stimulated foresight and planning for the future. Thus there is a reciprocal influence. ${ }^{22}$

The variable or precarious nature of children leads to the need for some way of providing for stability until the children achieve a capacity for engaging in the world as individuals.

However, the character of variability is not uniformly distributed across the human species, according to Dewey, nor is the character of stability. Variability is more a characteristic of human children than human adults, and stability more a characteristic of human adults. In the context of a rapidly changing environment characteristic of the industrial age, it is the childhood characteristic of variability which is at a premium, not the more static habits characteristic of adulthood.

Dewey sees a split between children and adults, historically though not logically. Adults frequently impose their rigid (stable) ways on children, hampering the balanced development of flexible conceptualization:

But the weight of adult custom has been thrown upon retaining and strengthening tendencies toward conformity, and against those which make for variation and independence. The habits of the growing person are jealously kept within the limit of adult customs. The delightful originality of the child is tamed. Worship of institutions and personages themselves lacking in imaginative foresight, versatile observation and liberal thought, is enforced. ${ }^{23}$

This tendency to restrict the flexible nature of childhood contradicts the nature of existence, the nature of present conditions and the nature of the human species. It is through the flexible nature of being human and the incorporation of such flexibility into the stable fabric of social relations, Dewey implies, that progress in human relations has emerged:

Plasticity and originality have been opposed to each other. That the most precious part of plasticity consists in ability to form habits of independent judgment and of inventive initiation has been ignored. For it demands a more complete and intense docility to form flexible easily re-adjusted habits than it does to acquire those which rigidly copy the ways of others. ${ }^{24}$

Adults in a democratic and industrialized society need to realize that children's characteristic capacity to alter their habits is to be nurtured, not suppressed. It is through children that adults can learn an essential aspect of what the human species (and indeed existence in general) is: a flexible, changing being. The task of education is to use that capacity to elicit a more stable life for the present and next generation while respecting that capacity among the young. Indeed, the capacity for flexibility among the young provides hope for the future of being human, since that capacity is characteristic of the scientific method and of the environment in an industrial society.

In human young, because of their incomplete initial nature, they are sub- 
ject to immense variations in their individual characters as they interact with their social and material environment. Individuality, in the sense of distinctness from others, constitutes a variation which in turn may become general (stable) as the variation becomes incorporated into human relations as a stable element between human beings:

For the most part, this continuous alteration has been unconscious and unintended. Immature, undeveloped activity has succeeded in modifying adult organized activity accidentally and surreptitiously. . . This is the meaning of education; for a truly humane education consists in an intelligent direction of native activities in the light of the possibilities and necessities of the social situation. ${ }^{25}$

Individual variations among children, if recognized by adults, furnish the possibility of the continuous incorporation of evanescent (precarious) features of being human into stable ones available to all through nurturing such individual variation rather than stifling it. The contrary case, however, has hitherto been the norm:

But for the most part, adults have given training rather than education. An impatient, premature mechanization of impulsive activity after the fixed pattern of adult habits of thought and affection has been desired... The younger generation has hardly even knocked frankly at the door of adult customs, much less been invited in to rectify through better education the brutalities and inequities established in adult habits. Each new generation has crept blindly and furtively through such chance gaps as have happened to be left open. Otherwise it has been modeled after the old. ${ }^{26}$

The characteristic of variability among children is more appropriate for an industrial society, where environmental conditions are frequently changing. Adults need to learn to become like children in this regard: to have an experimental attitude to the world, not the dogmatic attitude typical of many adults. Incongruent ideas proffered by children-incongruent from some adults' point of view-need to be considered seriously and not silenced or censored.

Although variability is, for Dewey, characteristic of childhood, the latter does have integrating or stabilizing features of its own. Thus, another characteristic of childhood relevant for the modern industrialized world is the child's whole-hearted interest in the world. Interest forms a necessary condition for the unification of the diverse aspects of action in one and only one direction; it provides focus to what otherwise would be a dispersal of energies in various contradictory directions. Interest in its fullest development absorbs the child, melding her total being into the activity at hand. This absorption in the task at hand explains the rapid development of babies:

The rapidity of mental development in the first year and a half of infancy, the whole-hearted intentness and absorption of the growing baby in his activities, the joy that accompanies his increase of ability to control his movements-all of these things are objects-lessons, writ large, as to the 
nature of interest, and the intellectual significance of actions that (externally judged) are physical. ${ }^{27}$

The concept of interest is thus linked to the precarious and the stable in a total manner. A habit or impulse which finds expression in an attempt to realize a purpose constitutes a moving unity of stable and unstable elements. The stable element is the controlled end or purpose which provides unity to the whole process or activity. ${ }^{28}$ The variable element is the various stimuli and responses that move the child toward her goal (altering the latter if necessary along the way). The unity is a moving unity, since the purpose functions ideally as a guide for the selection and moulding of means adequate to the purpose:

But in spite of this diversity, interests are one in principle. They all mark an identification in action, and hence in desire, effort, and thought, of self with objects; with, namely, the objects in which the activity terminates (ends) and with the objects by which it is carried forward to its end (means). Interest, in the emotional sense of the word, is the evidence of the way in which the self is engaged, occupied, taken up with, concerned in, absorbed by, carried away by, this objective subject-matter. At bottom all misconceptions of interest, whether in practice or in theory, come from ignoring or excluding its moving, developing nature; they bring an activity to a standstill, cut up its progressive growth into a series of static cross-sections. When this happens, nothing remains but to identify interest with the momentary excitation an object arouses. Such a relation of object and self is not only not educative, but it is worse than nothing. It dissipates energy, and forms a habit of dependence upon such meaningless excitations, a habit most adverse to sustained thought and endeavor. ${ }^{29}$

The interest of a child is similar to that of an animal: both integrate the totality of their senses and their bodies to the task at hand in a concentration of past as present (retrospective but pressing forward, as an urge swelling up that has functional efficacy in the present) and the future as anticipatory that also functions in the present as integrative. It is this unity of the totality of a child's and the nonhuman's being in the present that constitutes the aesthetic moment:

Art celebrates with peculiar intensity the moments in which the past reenforces the present and in which the future is a quickening of what now is.

To grasp the sources of esthetic experience it is, therefore, necessary to have recourse to animal life below the human scale. The activities of the fox, the dog, and the thrush may at least stand as reminders and symbols of that unity of experience which we so fractionize when work is labor, and thought withdraws us from the world. The live animal is fully present, all there, in all of its actions: in its wary glances, its sharp sniffings, its abrupt cocking of ears. All senses are equally on the qui vive. As you watch, you see motion merging into sense and sense into motion-constituting that animal grace so hard for man to rival. What the live creature retains from the past and what it expects from the future operate as directions 
in the present. The dog is never pedantic nor academic; for these things arise only when the past is severed in consciousness from the present and is set up as a model to copy or a storehouse upon which to draw. The past absorbed into the present carries on; it presses forward..$^{30}$

The presupposition for the whole-hearted engagement of children in their activity, of course, is the background stable environment of adults and the development of habits in the children. Adults, however, frequently engage in routine or mechanical behaviour, unable to unite the diverse elements of an experience into a moving unity that becomes aesthetic in character. ${ }^{31}$ Adults in modern society, where environmental conditions are changing relatively rapidly, would do well to adopt the virtue of whole-hearted interest characteristic of children ${ }^{32}$ because it is through whole-hearted interests that the variable is united with the stable in a total manner. ${ }^{33}$

Stable elements need to be constantly reconstructed, as human beings live on this earth generation after generation. That reconstruction, in modern democratic and scientific societies, depends in part on the unique capacity of children to be considerably more flexible than human adults, and that in a total manner. The modern world is the coming into being of respect for the characteristics of the human child, not in the sense of a necessity but in the sense of a need. If adult humans do not learn to become more like children in their dealings with each other and their material environment, they may well be incapable of dealing with the environment which they themselves have aided in creating.

Adults still need to develop environmental conditions in which children can learn to transform their unique characteristics of totalizing variability into a stable form that then serves as a point of departure for further totalizing variabilitygrowth-but the totalizing variability of children needs to be taken seriously and preserved in the process so that, as the children become adults, they retain their totalizing variable nature as much as possible.

This view of childhood does not mean that Dewey advocated a child-centered education. Rather, Dewey's view is that childhood and adulthood are two poles of one continuous process that, especially under modern conditions, need to be reconciled. Childhood, as the more variable and totalizing pole, needs adulthood to provide direction and thus stability via the formation of flexible habits; adulthood, the more stable pole, needs childhood to provide totalizing variation so that human beings do not remain stuck in routine or tradition in the face of changing environmental conditions. Childhood and adulthood are not opposed poles in modern society, but phases in a continuous process that can and needs to be harmonized under existing conditions:

With respect to the development of powers devoted to coping with specific scientific and economic problems we may say the child should be growing in manhood. With respect to sympathetic curiosity, unbiased responsiveness, and openness of mind, we may say that the adult should be growing in childlikeness. One statement is as true as the other. ${ }^{34}$ 
Nevertheless, unless adults learn to respect the distinctive characteristics of childhood, the human species, under industrial conditions, may well become extinct. The species may well prove itself incapable of controlling its own changing conditions of life.

In schools, it is the task of the curriculum and the teacher to provide the right balance between stability and precariousness in the environment in relation to the students' interests in order to ensure that children can realize their potentialities as human children through the acquisition of definite and general concepts. ${ }^{35}$

It has been shown that Dewey's generic traits of precariousness and stability underlie Dewey's philosophy of education by relating five elements of that philosophy to those generic traits: democracy, evolution, industrialization, the experimental method and childhood. Dewey's profound respect for childhood does not stem from a sentimental gloss on childhood, but is grounded in his metaphysics of stability and precariousness and their relative importance in modern society.

For those like Rorty and Gale, then, who would jettison Dewey's metaphysics, they must then jettison Dewey's philosophy of education, since the latter is grounded in his concepts of stability and precariousness; the concepts of stability and precariousness are implicit in Dewey's philosophy of education. Indeed, Dewey's philosophy of education is a concretization of his metaphysics; his metaphysics are implicit in his philosophy of education.

To argue against Dewey's metaphysics without considering the concretization of his metaphysics, as do Rorty and Gale, is insufficient. Dewey, like Hegel before him, tried to concretize his metaphysics in diverse directions, but unlike Hegel, he formalized his metaphysics in Experience and Nature only after, to a certain extent, he had already implicitly concretized it in earlier works.

Of course, whether Dewey's metaphysics is sound or not remains an issue to be decided, but it is beyond this article to address the issue extensively. The issue can, nevertheless, be adumbrated by examining the view that Dewey had no metaphysics and, when he did venture into the metaphysical realm, he became mystical. For example, Charlene Seigfried argues that, on balance, it would be better to conclude that Dewey did not develop a metaphysics at all. ${ }^{36}$ That Dewey wished to avoid and indeed to criticize metaphysics in the traditional sense of an ontology of fixed categories or relations is indisputable. Nevertheless, there are grounds for considering what he is was doing in Experience and Nature (and other works) as metaphysical in the sense of a general theory of nature and experience based on inferences through experiential inquiry itself. The generic traits of existence were conclusions derived from an inquiry into the nature of experience and nature and did not stand outside the process of inquiry. At the same time, the conclusions, like all conclusions of warranted inquiry, were meant to be used to guide further inquiry.

The issue can be addressed in Seigfried's own terms: the issue of temporal quality and temporal order. Seigfried refers to the issue in the following passage:

Immediate qualities seem to be the lynchpin of Dewey's attack on this fundamental dualism of modernity. Oddly enough, even temporality is 
characterized as a quality. So, what is a 'quality'? It is "direct, immediate, and undefinable" (LW 1:92). It is what is directly had in the presence of objects/events/occurrences. In contrast to the qualitative immediacy of temporality, "order is a matter of relation, of definition, dating, placing and describing. It is discovered in reflection, not directly had and denoted as is temporal quality. Temporal order is a matter of science; temporal quality is an immediate trait of very occurrence whether in or out of consciousness" (LW 1:92).

With these explicit claims, we reach an impasse in this inquiry into whether Deweyan pragmatism includes a metaphysics. The problem is that in passages like the ones quoted above, Dewey's instrumental pragmatism succumbs to the same contradictions that James's radically empirical pragmatism also sometimes does when he falls back on traditional divisions instead of being consistently pragmatist. Both want to overcome the great philosophical dualism of a forced choice between privileging empiricist givens or idealist takings; of deciding whether to subscribe to intuitive immediacy as the source of knowledge, as empiricists do, or to reflective reconstruction, as idealists do. Both develop an original pragmatist overcoming of these fundamental dualisms, one based on the simultaneity of doing and undergoing, of concreteness and selective interest. But both at times fall back into claiming the priority of the given, which their own more incisive analysis precludes. The metaphysical passage above is one such instance in Dewey. ${ }^{37}$

Seigfried judges the distinction between temporal quality, which, she argues, is given in experience, and temporal order, which, she argues, is taken in experience, as a contradiction within Dewey's theory, and this contradiction reflects a metaphysical—or mystical—flaw in his work.

However, if we look more closely at what Dewey wrote and implied about temporal quality and temporal order, the question of the relation of temporal quality and temporal order becomes clearer. Dewey considered all qualities, as existences, as immediate. Every immediate existence (as Dewey argued extensively in chapter 3 of Experience and Nature) is an event. Immediate existences, as events, are characterized by at least three aspects: finalities, beginnings and mediations. With respect to finalities, Dewey had this to say:

Any quality as such is final; it is at once initial and terminal; just what it is as it exists. It may be referred to other things, it may be treated as an effect or as a sign. But this involves an extraneous extension and use. It takes us beyond quality in its immediate qualitativeness. If experienced things are valid evidence, then nature in having qualities within itself has what in the literal sense must be called ends, terminals, arrests, enclosures. ${ }^{38}$

All existences, as events, are terminal. However, as Dewey indicated in the above passage, all events as terminal are-simultaneously_initial or are beginnings. Dewey developed the idea of the simultaneous characteristic of events as beginnings and endings in the following passage: 
The genuine implications of natural ends may be brought out by considering beginnings instead of endings. To insist that nature is an affair of beginnings is to assert that there is no one single and all-at-once beginning of everything. It is but another way of saying that nature is an affair of affairs, wherein each one, no matter how linked up it may be with others, has its own quality. ... And since wherever one thing begins something else ends, what is true of beginnings is true of endings. ${ }^{39}$

All existences, as events, are simultaneously beginnings and endings. There is no "past, present or future" separation characteristic of temporal order. Existences are simultaneously beginning and endings.

The same could be said of existences as mediations, or events that are becoming other than what they are in their uniqueness: Seigfried's quoted passage continues:

Every event as such is passing into other things, in such a way that a later occurrence is an integral part of the character or nature of present existence. An "affair", Res, is always at issue whether it concerns chemical change, the emergence of life, language, mind or the episodes that compose human history. ${ }^{40}$

Every event, then, is simultaneously a beginning, an end and a mediating moment. The latter indicates that immediacy as temporal quality has a vector-like aspect. There is no existence that does not contain all elements simultaneously. Experience of this temporal quality of any event is synonymous with having an experience; it does not imply that there is knowledge of that experience of the person undergoing the experience.

Although all events are simultaneously a beginning, an end and a mediation, spatio-temporal spread requires inquiry. ${ }^{41}$ Characterization of spatio-temporal relations, in other words, requires the determination of temporal order through a process of inference and inquiry. People experience temporal qualities when they have an experience, but they do not know those qualities.

Again, instead of arguing directly and extensively for the view that Dewey had a metaphysics, a look at a concretization of Dewey's distinction between temporal quality and temporal order may illustrate the usefulness of such a distinction and hence the usefulness and relevance of Dewey's metaphysics of experience.

An example drawn from an unusual source may also provide a clearer distinction of the nature and connection of temporal quality and spatio-temporal spread, or temporal order: Karl Marx's theory of the circuits of capital. ${ }^{42}$ The first circuit of capital is the money circuit of capital, which contains all the elements of the other circuits, but in a different order. Thus, the money circuit of capital consists of $\mathrm{M} 1-\mathrm{C} 1(=\mathrm{MP}+\mathrm{L}) \ldots \mathrm{P} \ldots \mathrm{C} 2-\mathrm{M} 2$, where

M1 = the money invested; $-=$ an exchange; $\mathrm{C} 1=$ the commodities purchased for investment purposes (which consist of $\mathrm{MP}$ - means of production-and L-labour power); . . = an interruption in the circulation or 
exchange process; $\mathrm{P}=$ the capitalist production process; $\mathrm{C} 2=$ the commodity output, with $\mathrm{C} 2$ greater in value than $\mathrm{C} 1$; and $\mathrm{M} 2$ = the return of the money invested, with $\mathrm{M} 2=\mathrm{C} 2$, but greater in quantity than $\mathrm{M} 1 .^{43}$

The other two circuits have a different beginning, end and middle. Thus, the commodity circuit of capital consists of $\mathrm{C} 2-\mathrm{M} 2, \mathrm{M} 1-\mathrm{C} 1 \ldots \mathrm{P} \ldots \mathrm{C} 2$, where M2 becomes M1 (a new beginning once the previous money circuit of capital has been realized). Similarly, the productive circuit of capital consists of P . . C2 - M2, $\mathrm{M} 1-\mathrm{C} 1$. . . P. If the three circuits of capital are analyzed together in relation to one stage (purchase, production or sale), it can be seen that each stage is simultaneously beginning, middle and end: "Each moment appears as a point of departure, of transit, and of return." ${ }^{44}$ For instance, the conversion of C2 into M2 is an end for the money circuit of capital, a beginning for the commodity circuit of capital and a mediation for the productive circuit of capital. Those workers who sell C2 for M2 experience the simultaneity of all three without necessarily understanding the temporal conditions for each to occur. These conditions are established by the inquirer, who then develops the immediate experience into the expanded forms of the money circuit of capital, the commodity circuit of capital and the productive circuit of capital, but the workers need not know the nature of the experience which they have. Having an experience, which necessarily involves temporal quality, need not entail an understanding of the experience; the latter requires inference involving the past and the future.

Dewey's distinction between temporal quality and temporal order, which Seigfried finds metaphysical, is cogent when concretized and constitutes an example of Dewey's new metaphysics - a metaphysics of experience.

Thus, the validity of Dewey's new metaphysics of experience is partially a function of its concretization. Just as the concretization of the concepts of temporal quality and temporal order provides a window on the world in which we live, so too do the concepts of stability and precariousness. Indeed, the connection of the concepts of stability and precariousness with the five elements of democracy, evolution, industrialization, the experimental method and childhood (as well as adulthood) provides a coherent philosophy of education relevant for the modern world.

Other issues remain even if Dewey's new metaphysics is considered sound. The above analysis has used the concepts of "childhood" and "adulthood" as if they were monolithic concepts without distinctions relevant to the issue of Dewey's metaphysics. Dewey's distinctions within each category, however, may also be relevant to the question of Dewey's metaphysics. Only further research can decide that.

Another question relates to the curriculum established in the Laboratory School at the University of Chicago. To what extent a curriculum based on occupations linked to the production and consumption of the basic needs of all human beings - food, clothing and shelter — is connected to Dewey's concepts of stability and precariousness also requires research, as do the links to Dewey's concepts of democracy, evolution, industrialization, the experimental method and childhood (and adulthood). 
Finally, the article merely connects two generic traits of existence specified by Dewey to his philosophy of education. To what extent other generic traits are related to his philosophy of education, if at all, needs to be investigated. So too do the concepts of temporal quality and temporal order.

Hence, the issue of Dewey's metaphysics and its relation to his philosophy of education provides plenty of research possibilities. This article merely represents one of those possibilities.

\section{Notes}

1. Richard Rorty, Consequences of Pragmatism: Essays: 1972-1980 (Minneapolis: University of Minnesota Press, 1982), 72-89.

2. Richard M. Gale, "The Metaphysics of John Dewey," Transactions of Charles S. Pierce Society, 38, no. 4 (2002), 498-500.

3. Raymond Boisvert, Dewey's Metaphysics (New York: Fordham University Press, 1988).

4. Boisvert, Metaphysics, 107.

5. John Dewey, Experience and Nature, in The Later Works, 1925-1953, vol. 1, ed. Jo Ann Boydston (Carbondale: Southern Illinois University Press, 1981), 55.

6. John Dewey, Democracy and Education, in The Middle Works, 1899-1924, vol. 9, ed. Jo Ann Boydston (Carbondale: Southern Illinois University Press, 1980), ix.

7. Ralph Sleeper, The Necessity of Pragmatism: John Dewey's Conception of Philosophy (New Haven: Yale University Press, 1986), ix.

8. Dewey, Democracy and Education, 3.

9. John Dewey, How We Think, in The Middle Works, 1899-1924, vol. 6, ed. Jo Ann Boydston (Carbondale: Southern Illinois University Press, 1978), 179.

10. Tim Ingold, Evolution and Social Life (Cambridge: Cambridge University Press, 1986, 8-9) points out that the key to Darwin's theory of evolution is his view that individual variation forms the basis for evolution, not species or kinds.

11. Dewey, Democracy and Education, 93.

12. Dewey, Democracy and Education, 95-96.

13. Dewey, Democracy and Education, 96.

14. Dewey, Democracy and Education, 89.

15. Robert Westbrook, John Dewey and American Democracy (Ithaca: Cornell University Press, 1991), 224-227. The question of the adequacy of Dewey's critique of capitalism is addressed in another essay. See Fred Harris, "Dewey's Materialist Philosophy of Education: A Resource for Critical Pedagogues?” European Legacy, 11, no. 3 (2006), 259-288.

16. Dewey, How We Think, 312.

17. Dewey's colleague George Herbert Mead also emphasized the importance of experimental variation in conditions, the emergence of the unique through such variation and the reconstruction of the conceptual structure through the incorporation of such apparent anomalies. See Alfred S. Clayton, Emergent Mind and Education: A Study of George H. Mead's Bio-social Behaviorism from an Educational Point of View (New York: Teachers College, Columbia University, 1943), 5-20.

18. Dewey, Democracy and Education, 93.

19. Dewey, Democracy and Education, 93-94. 
20. Dewey, Democracy and Education, 94.

21. Dewey, Democracy and Education, 48.

22. Dewey, Democracy and Education, 50.

23. John Dewey, Human Nature and Conduct: An Introduction to Social Psychology, in The Middle Works, 1899-1924, vol. 14, ed. Jo Ann Boydston (Carbondale: Southern Illinois University Press, 1983), 70-71.

24. Dewey, Human Nature, 70.

25. Dewey, Human Nature, 69-70.

26. Dewey, Human Nature, 70.

27. John Dewey, Interest and Effort in Education, in The Middle Works: 1899-1924, vol. 7, ed. Jo Ann Boydston (Carbondale: Southern Illinois University Press, 1979), 184-185.

28. Dewey, How We Think, 202.

29. Dewey, Interest and Effort, 194-195.

30. John Dewey, Art as Experience, in The Later Works, 1925-1953, vol. 10, ed. Jo Ann Boydston (Carbondale: Southern Illinois University Press, 1987), 24.

31. Michael L. Schwalbe, The Psychosocial Consequences of Natural and Alienated Labor (Albany: State University of New York Press, 1986), provides an analysis of different degrees of aesthetic labour among different sets of workers using a Marxian/Meadian model.

32. Frank X. Ryan, Circles of Inquiry: John Dewey's Philosophy of Transaction (Ph.D. diss., Emory University, 1996), 633, points out that one of Dewey's few specifications of virtue involves whole-heartedness.

33. Ryan, Circles, 388, argues that the generic traits of existence, since they are connected to a history in primary experience, can be distributed over time:

2) Because a "unit" of existence in primary experience is not a synchronic "slice" but historic and enduring, a trait may be truly generic without being ubiquitous so long as it "hooks up" with other events in a connected series. This eliminates the objection that mutually exclusive traits such as the precarious and the stable, beginning and end, cannot be generic to all existences at all times. Instead, given that each member of a series is integral to the whole, a trait is considered generic if it occurs at some point in any history.

The argument here complements his view in that the generic traits of existence can be distributed over generations, with both needing their other in order to be whole.

34. Dewey, Democracy and Education, 55.

35. Dewey, How We Think, 153-154.

36. Charlene Seigfried, "Ghosts Walking Underground: Dewey's Vanishing Metaphysics," Transactions of Charles S. Pierce Society, 40, no. 1 (2004), 53.

37. Seigfried, "Ghosts," 74.

38. Dewey, Experience and Nature, 82.

39. Dewey, Experience and Nature, 83.

40. Dewey, Experience and Nature, 92.

41. Ryan, Circles of Inquiry, 139.

42. Karl Marx, Capital: A Critique of Political Economy, vol. 2, trans. David Fernbach (New York: Vintage Books, 1978), 109-206. 
43. Harris, "Dewey's Materialist Philosophy," 283.

44. Marx, Capital, vol. 2, 180.

\section{References}

Boisvert, Raymond. Dewey's Metaphysics. New York: Fordham University Press, 1988. Clayton, Alfred S. Emergent Mind and Education: A Study of George H. Mead's Biosocial Behaviorism from an Educational Point of View. New York: Teachers College, Columbia University, 1943.

Dewey, John. Interest and Effort in Education. The Middle Works: 1899-1924. Vol. 7. Edited by Jo Ann Boydston. Carbondale: Southern Illinois University Press, 1979.

— Democracy and Education. The Middle Works: 1899-1924. Vol. 9. Edited by Jo Ann Boydson. Carbondale: Southern Illinois University Press, 1980.

_. Experience and Nature. The Later Works, 1925-1953. Vol. 1. Carbondale: Southern Illinois University Press, 1981.

- Human Nature and Conduct: An Introduction to Social Psychology. The Middle Works, 1899-1924. Vol. 14. Edited by Jo Ann Boydston. Carbondale: Southern Illinois University Press, 1983.

_ . Art as Experience. The Later Works, 1925-1953. Vol. 10. Edited by Jo Ann Boydston. Carbondale: Southern Illinois University Press, 1987.

- How We Think: A Restatement of the Relation of Reflective Thinking to the Education Process. Lexington, Mass.: Heath, 1933.

Gale, Richard G. “The Metaphysics of John Dewey.” Transactions of Charles S. Pierce Society, 38, no. 4 (2002), 477-519.

Harris, Fred. "Dewey's Materialist Philosophy of Education: A Resource for Critical Pedagogues?" European Legacy, 11, no. 3 (2006), 259-288.

Ingold, Tim. Evolution and Social Life. Cambridge: Cambridge University Press, 1986.

Marx, Karl. Capital: A Critique of Political Economy. Vol. 2. Translated by David Fernbach.

New York: Vintage Books, 1978.

Rorty, Richard. Consequences of Pragmatism: (Essays: 1972-1980). Minneapolis: University of Minnesota Press, 1982.

Ryan, Frank X. Circles of Inquiry: John Dewey's Philosophy of Transaction. Unpublished doctoral dissertation. Atlanta, Ga.: Emory University, 1996.

Schwalbe, Michael L. The Psychosocial Consequences of Natural and Alienated Labor. Albany: State University of New York Press, 1986.

Seigfried, Charlene. "Ghosts Walking Underground: Dewey's Vanishing Metaphysics," Transactions of the Charles S. Peirce Society, 40, no. 1 (2004).

Sleeper, Ralph. The Necessity of Pragmatism: John Dewey's Conception of Philosophy. New Haven: Yale University Press, 1986.

Westbrook, Robert. John Dewey and American Democracy. Ithaca: Cornell University Press, 1991.

Fred Harris is a doctoral candidate in the Department of Educational Foundations, Administration and Psychology at the University of Manitoba.

Email: arbeit67@hotmail.com 